\title{
A Sequence-Ready BAC Contig of the GABA Receptor Gene Cluster Gabrgl-Gabra2-Gabrb1 on Mouse Chromosome 5
}

\author{
Andreas Lengeling, ${ }^{1}$ Tim Wiltshire, ${ }^{1}$ Chris Otmani, ${ }^{1}$ and Maja Bućan ${ }^{1-3}$ \\ ${ }^{1}$ Center for Neurobiology and Behavior, Department of Psychiatry, and ${ }^{2}$ Department of Genetics, University of Pennsylvania, \\ Philadelphia, Pennsylvania 19104 USA
}

\begin{abstract}
The type-A receptors for the neurotransmitter GABA ( $\gamma$-aminobutyric acid) are ligand-gated chloride channels that mediate postsynaptic inhibition. The functional diversity of these receptors comes from the use of a large repertoire of subunits encoded by separate genes, as well as from differences in subunit composition of individual receptors. In mammals, a majority of $\mathrm{GABA}_{\mathrm{A}}$ receptor subunit genes are located in gene clusters that may be important for their regulated expression and function. We have established a high-resolution physical map of the cluster of genes encoding $\mathrm{GABA}_{\mathrm{A}}$ receptor subunits $\alpha 2$ (Gabra2), $\beta 1$ (Gabrbl), and $\gamma_{1}$ (Gabrgl) on mouse chromosome 5. Rat cDNA probes and specific sequence probes for all three $G A B A_{A}$ receptor subunit genes have been used to initiate the construction of a sequence-ready contig of bacterial artificial chromosomes (BACs) encompassing this cluster. In the process of contig construction clones from 129/Sv and C57BL/6] BAC libraries were isolated. The assembled 1.3-Mb contig, consisting of $45 \mathrm{BACs}$, gives five- to sixfold coverage over the gene cluster and provides an average resolution of one marker every $32 \mathrm{~kb}$. A number of BAC insert ends were sequenced, generating 30 new sequence tag sites (STS) in addition to 6 Gabr gene-based and 3 expressed sequence tag (EST)-based markers. STSs from, and surrounding, the Gabrgl-Gabra2-Gabrbl gene cluster were mapped in the T31 mouse radiation hybrid panel. The integration of the BAC contig with a map of loci ordered by radiation hybrid mapping suggested the most likely genomic orientation of this cluster on mouse chromosome 5: cen-D5Mit151-Gabrg1-Gabra2-Gabrb1-D5Mit58-tel. This established contig will serve as a template for genomic sequencing and for functional analysis of the $\mathrm{GABA}_{\mathrm{A}}$ gene cluster on mouse chromosome 5 and the corresponding region on human chromosome 4.
\end{abstract}

The sequence data described in this paper have been submitted to the GenBank/GSS data libraries under accession nos. AF156490 and AQ589406-AQ589436.

$\gamma$-Aminobutyric acid (GABA) is a potent inhibitory neurotransmitter in the central nervous system (CNS) that interacts with two different classes of GABA receptors: the ionotrophic $\mathrm{GABA}_{\mathrm{A}}$ receptor chloride channels (for review, see Rabow et al. 1995; Seeburg et al. 1990) and the recently cloned metabotropic G-proteincoupled $\mathrm{GABA}_{\mathrm{B}}$ receptors (Kaupmann et al. 1997, 1998).

$\mathrm{GABA}_{\mathrm{A}}$ receptors are multimeric membranespanning ligand-gated ion channels that admit chloride on binding of the neurotransmitter GABA (Bormann et al. 1987). Because GABA is the major inhibitory neurotransmitter of the CNS, modulation of receptor activity has profound implications for both brain function and therapy of various neuropsychiatric disorders. Drugs that alter the $\mathrm{GABA}_{\mathrm{A}}$ receptor channel activity, such as benzodiazepines, barbiturates, and steroids, have had important roles in the understanding and treatment of anxiety, sleep disorders, convulsive disorders, and epilepsy (for review, see Burt and Kamat-

${ }^{3}$ Corresponding author.

E-MAIL bucan@pobox.upenn.edu; FAX (215) 573-2041. chi 1991; Brooks-Kayal et al. 1998; Shiah and Yatham 1998).

Functional studies of the individual $\mathrm{GABA}_{\mathrm{A}}$ receptor genes have been hindered by a high structural diversity among the $\mathrm{GABA}_{\mathrm{A}}$ receptor subunits that assemble combinatorially to build different subtypes of $\mathrm{GABA}_{\mathrm{A}}$ receptors in various regions of the brain and the spinal cord. To date nineteen distinct subunit types $(\alpha 1-\alpha 6, \beta 1-\beta 4, \gamma 1-\gamma 4, \delta 1, \epsilon, \rho 1-\rho 3)$ have been identified and this isoform complexity is further complicated by the occurrence of alternative splicing and posttranslational modifications (Wisden and Seeburg 1992). In the mammalian genome, many $G_{A B A}$ receptor subunit genes are organized as gene clusters on different chromosomes, with each of these clusters containing at least one gene of the $\alpha, \beta$, and $\gamma$ or $\epsilon$ class. In humans, five $\mathrm{GABA}_{\mathrm{A}}$ receptor subunit gene clusters have been described. The GABRB2-GABRA1/GABRA6GABRG2 cluster on human chromosome (HSA) 5q31.2-q35 (Kostrzewa et al. 1998) is homologous to the cluster on mouse chromosome (MMU) 11 (Garrett et al. 1997). Similarly, the GABRB3-GABRA5-GABRG3 gene cluster, located close to the Prader-Willi/ 
Angelman region on HSA 15q11-q13 (Glatt et al. 1997; Christian et al. 1998), corresponds to the Gabrb3Gabra5-Gabrg3 cluster located distal to the pink-eyed dilution ( $p$ ) gene region on MMU 7 (Nakatsu et al. 1993; Culiat et al. 1994). An additional cluster, containing the GABRA3, GABRB4, and GABRE2 subunit genes, has been mapped to human chromosome Xq28 (Levin et al. 1996; Wilke et al. 1997) and mouse chromosome X (Boyd et al. 1998). Two GABA subunit genes, $\rho 1$ and $\rho 2$, expressed at a high level in the retina, have been shown to map to HSA $6 q 11-q 14$ and the corresponding region in the proximal portion of $\mathrm{MMU}$ 4 (Cutting et al. 1992).

In humans, the GABRA2, GABRG1, and GABRB1 genes have been mapped to HSA 4p12-p13 (Buckle et al. 1989; Kirkness et al. 1991; Wilcox et al. 1992). Furthermore, somatic cell hybrid analysis has indicated that the GABRA4 gene maps to the same cluster (McLean et al. 1995). The murine orthologs, Gabra2 and Gabrb1 subunit genes, have been localized to the central portion of MMU 5, whereas the Gabra4 subunit gene has been assigned to proximal MMU 7 (Danciger et al. 1993). We have previously placed the murine Gabrb1 locus on a long-range restriction map, $3 \mathrm{Mb}$ proximal to the dominant spotting locus $(W)$ encoded by the proto-oncogene c-Kit (Nagle et al. 1995). To gain insight into the genomic organization of the $\mathrm{GABA}_{\mathrm{A}}$ receptor gene cluster on mouse chromosome 5, we have constructed a sequence-ready bacterial artificial chromosome (BAC) contig of $1.3 \mathrm{Mb}$. This contig has been anchored to other chromosome 5 loci using radiation hybrid $(\mathrm{RH})$ mapping, and the transcriptional orientation of two $\mathrm{GABA}_{\mathrm{A}}$ receptor subunit genes, Gabra2 and Gabrb1, has been determined. This highresolution physical map will provide the basis for functional characterization and sequencing of genes located in this cluster.

\section{RESULTS}

The contig spanning the $\mathrm{GABA}_{\mathrm{A}}$ receptor genes in the central portion of mouse chromosome 5 was generated in the following steps: (1) initial hybridization screen; (2) STS content mapping; (3) chromosome walk using selected STSs generated from BAC ends; and (4) fine mapping by fingerprinting and Southern blot analysis. To initiate the construction of a BAC contig, we used Gabra2 and Gabrg1 rat cDNA probes and a mouse Gabrb1 cDNA clone to screen two 129/Sv BAC libraries. We isolated $27 \mathrm{BAC}$ clones, and 23 were confirmed to correspond to $\mathrm{GABA}_{\mathrm{A}}$ receptor genes by dot-blot colony assays and by Southern blot analysis. The BACinsert sizes were determined by pulsed field gel electrophoresis (PFGE) following a NotI digestion of BAC DNA.

Table 1. Primers and PCR Conditions for STSs and Genes in the Contig

\begin{tabular}{|c|c|c|c|c|c|c|}
\hline $\begin{array}{l}\text { BAC end / gene } \\
\text { probe }\end{array}$ & Locus & Accession No. & Forward primer & Reverse primer & $T_{\text {Ann }}\left({ }^{\circ} \mathrm{C}\right)$ & slze (bp) \\
\hline 241N21.SP6 & DSBUCE & AQ589407 & $5^{\prime}$-AAT CAT TGT CCC GAA ATC CC- $3^{2}$ & 5'-GAT GAT ATG AGC AGC ATG GC-3' & 55 & 214 \\
\hline 337019.77 & D5BuC7 & $\overline{A Q 5894 \overline{14}}$ & 5'-CAT CAG GCC TCA CAT GAG TAA TCC- 3 ' & 5'-GTG ATT GCT GTT TTA TTC AAT AGG-3' & 58 & 207 \\
\hline $344 \mathrm{~L} 2 . \mathrm{TT}$ & D5BUC8 & AQ589416 & 5'-TAC TाT GGG AGG TGA TTG CC-3' & 5'ATG AAA TGG TGA GGC TCC AG-3, & 55 & 194 \\
\hline $3^{3}-$ Gebrg1 & Gabrg1 & AF156490 & 5-TCC CTA ACA CCCT TTA ACA ATG AGC-3' & 5'-ATA CTG TGA GAA TTA TAG TTG TCC-3' & 58 & 325 \\
\hline 5 -Gabrgt & Gabrg1 & AF 158490 & $5^{\prime}-$ GGC $T$ C CCC AGG TCT CCA TGC TGG-3' & 5'-TAT CCG CCC TTC CCT CCA GGA CCC- 3 & 59 & 145 \\
\hline $350123 . \mathrm{SPG}$ & D5BuC9 & AQ589417 & 5'-TIT GAA GTT TGG CAQ AGA AAG-3' & 5.CAG CCA TTG CAT TTG ATG TC- $3^{\prime}$ & 58 & 204 \\
\hline $241 \mathrm{~N} 21 . \mathrm{T7}$ & DEBLC10 & $A Q 58940 B$ & 5'-TGC TCT TTA TTG GCA TCA CC- 3 & 5'-TCT TIT TGT CCA AAG AAT TAT GC-3' & 55 & 154 \\
\hline 337019.SP6 & D58uc11 & $A 0589413$ & 5'-TCC TCA GTI GIT TGG CAT TAT GCC-3 & $5^{\prime}$-Tा ACT CAC TCT TII AGT AAA GGC-3' & 58 & 212 \\
\hline 437P3.SPG & DSBuc12 & AQ589435 & 5'-AAG CTT TGG CCT GTT CCT ACT AGC-3' & 5'-GCA GGA TTA GAA GT GGT TCA TCC-3' & 58 & 211 \\
\hline 344L2.SPB & D5BuC13 & AQ589415 & 5'-TGA ATA TTG CAG TGG ATG GC-3' & 5'-CAA GCA ACC TTG CTA TGC AG-3' & 58 & 183 \\
\hline 441119.77 & D5BuC14 & $\mathrm{AO} 589427$ & 5'-AAC TTA GAG CCT GGT GTG TGG-3' & 5'-AGG CAAAAT CCC ACC AAA G-3' & 60 & 151 \\
\hline 3-Gabra2 & Gabra2 & M86507 & 5'-TTG TAC AGT CTG ACT AAT AAC TGC-3' & 5'-TGA AAC CCA CTT TAA ACT AGT TCC-3' & 58 & 203 \\
\hline $536 \sqrt{3} .77$ & D5Buc15 & AQ589436 & 5'-AGC CAT GTG GAT CAC TGT TTC-3' & $5^{\prime}$-GCC ATA TAT GCA TAG TGA ACC TG-3' & 57 & 218 \\
\hline $5 F 3 . T 7$ & D5Buc10 & AQ589434 & 5'-GTG TGA TAA CAG TTT TAT CAAAGG-3' & $5^{\prime}-\mathrm{CCC}$ ATT TCA CTA AAT GTA GAG TGC-3' & 58 & 151 \\
\hline $5 F 3 . S P 6$ & \begin{tabular}{|l|l|} 
D5EUC17 \\
\end{tabular} & AQ589433 & $5^{\prime}$-AAA GGGC ATC TAC ATA TAA TTC AGG-3' & $5^{\prime}$-ATG TAG AGT GCT TTG TGA CAA AGG-3' & 58 & 220 \\
\hline $253 \mathrm{~K} 12 . \mathrm{T7}$ & D5Buc18 & A0589411 & 5'-TCA GAC CTC CTG CTI TCA TGC TGG-3' & $5^{\circ}-A C A$ T G TAA TCA CTG CAA AAG ACG-3' & 58 & 227 \\
\hline 5 5'-Gebra2 & Gabra2 & M86567 & 5'-AAA TTG AGC ACA TGC AAT GTA TGG-3' & $5^{\prime}$-CTA AGC CGA TTA TCA TAA CCA TCC-3' & 59 & 1700 \\
\hline $37 L 14, T 7$ & D58uc19 & $A Q 589420$ & 5'-GTC TCC ACT CAG AGC TGT TAG TCC-3' & $5^{\prime}-$ TCC ACG GTT ACT TIT CGT CAT GCC-3' & 58 & 223 \\
\hline $432 \mathrm{~N} 14 . \mathrm{T} 7$ & DSEUC20 & AQ589426 & 5'-ПTG TAG TIA TIA ATA CTC TAC TCC-3' & $5^{\prime}$-AAG AGA AGT ATT TCT CAG AGG-3' & 55 & 290 \\
\hline D5Mit306 & DEMit305 & & 5'-AAG ATG GGA AAA TCA GGG ATG-3' & 6'-AAA TGT TCC CTT CAT TIT CTT CC- $3^{\prime}$ & 55 & 106 \\
\hline $351 F 9.77$ & DSBUC21 & AQ0589419 & 5'-AGG CTG ATG TTG AAA CCT GC-3' & $5^{\prime}$-CCA ATG CTC TAG AAA GCC AGG-3' & 55 & 155 \\
\hline $381 \mathrm{P} 13 . \mathrm{SP} 6$ & DEBuc22 & AQ589421 & 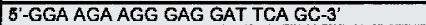 & 5'-AGG CAG CTT TTC CTA ATC CC-3' & 55 & $\overline{172}$ \\
\hline 449H5.SPG & D5Buc23 & $A Q 589428$ & 5'-TGT CACAGC AGA AAC CTT GC-3' & 5'-AAC CAG GAA ACG GAC AAA TG.3' & 57 & 311 \\
\hline IMAGE:1069176 & D5Buc240 & AA792909, AQ589428 & $5^{\prime}$-AAC CCA TAT CTC ATT CTG TGG AGG-3' & 5'-AGG CCG TGT GTG AGC AGC TCC TGG-3' & 59 & 195 \\
\hline 5'-Gabrb1 & Gabrb1 & U14418 & 5'-TCC TCC TCC TCT TCT TCC TTC TCC-3' & $5^{\prime}$-CCT CAT CTA CTA TGC ACT GAG TGO-3. & 58 & 180 \\
\hline 388L8.SP6 & D5BUC25 & AQ589423 & 5'-TGT GTA TCA TCC CAT GTC AAG ATC-3' & 5'ATG GCT ATT CCT GGC GGT CAC C-3' & 59 & 138 \\
\hline IMAGE: 1858590 & $D 5 B \cup C 206$ & Al272450, AO589418 & 5'-CTG TGA TAA TCC TGG TGG GC-3' & 5'-TTG CCT TTC TGT CGT AGC TG-3' & 55 & 154 \\
\hline Gabr Rept & D5BUC27 & $A 0589406$ & 5'ATT CTA CCT GGT TCT GCG TAG TCC-3' & $5^{\circ}$-AGG GGA TCA CACAGA TCT CCA ACCC-3' & 58 & 615 \\
\hline $388 \mathrm{~L} 8 \mathrm{TT}$ & DSBUC28 & $A Q 589424$ & 5'ATG TGA GAG CCA GGT TAT GGA TCC-3' & 5'-GTA AAG AGG TTT AGA TCA TGA AGGG-3' & 59 & 257 \\
\hline $556 \mathrm{~B} 6 . \mathrm{SPE}$ & 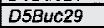 & AQ589431 & 5'-GTG TTT TGT GTG TTC AGC CG-3' & 5'-TCA AAA GTC TCC AGC GTG TG-3' & 60 & 276 \\
\hline 3'-Gabb1 & Gabrb1 & U14418 & 5'-GAG GTA AGA GAT TCA GCC $\pi T C$ CAG-3' & $5^{\circ}-\mathrm{CCA}$ GGG TAA CTG AGA AAG ACT GC-3' & 58 & 230 \\
\hline Brain EST MDB081B & \begin{tabular}{|l|l|l}
$05 B_{u} 30_{9}$ \\
\end{tabular} & R74668, AQ5899431 & 5'-TTA ATG GGA AAT GTC TGC CAT GGG-3' & 5'-CTG GAA TGGA TTGG AAA ATG TAA TGG-3' & 58 & 164 \\
\hline 381P13.T7 & DSEuc.31 & $A Q 589422$ & 5'-GCC GAA GCT GAA AAG ATG AG-3' & $6^{2}-$ GGG AAC TGC AGA GTा CAA GC-3' & 55 & 185 \\
\hline 249LL.SP6 & D5Buc32 & AQ589409 & $5^{\prime}$-CAG AAA TGT GGG AGG AGA GG-3 & $5^{\prime}$-ATA AAT GCA GGG GTG GTC TG-3' & 57 & 186 \\
\hline $503 \mathrm{D} 21 . \overline{17}$ & DSBUC33 & $A 0589430$ & $5^{\prime}$-CGA TTC TTC TGA CTEAGC CC-3' & 5'-TGT CAC TGG CAT CTG CCT AC-3' & 56 & 263 \\
\hline $393 M 12 . S P B$ & D5Buc34 & $A Q 589425$ & 5'-CAG CCT CTG TIT TAC TCG TTC ACC-3' & 5'-ATA AGC ATG TCA GTA TIG AAG TGC-3' & 58 & 247 \\
\hline $249 \mathrm{~L} 8 . \mathrm{T}$ & D5Buc35 & $\overline{A Q 58 \overline{9} \overline{410}}$ & $5^{\prime}$-CCT TTG GTT TTC GCA ATC TC- $3^{\prime}$ & $5^{\prime}$-CAC TCCATT TCC CCC ATI C-3' & 57 & 196 \\
\hline $556 \mathrm{BB} . \mathrm{T7}$ & D5Buc36 & $A Q 589432$ & 5'-TAC TGA ACC CTT GCC TGT CC-3' & 5'-AAA GAA AAT CCA TGC GGT TOT-3' & 60 & 233 \\
\hline $335 K 24 . T 7$ & \begin{tabular}{|l|l}
$05 B u c 37$ \\
\end{tabular} & $A 0589412$ & 5'-AGA ACA TCA TCT TIT AAC TTC ACT AGG-3' & $5^{\prime}$-CAG CCA ATT TCA TIT TIA TAG ATT CC-3' & 55 & 176 \\
\hline 603D21.SP6 & \begin{tabular}{|l|l|} 
DEBuc38 \\
\end{tabular} & AQ589429 & $5^{\prime}$-ACA GGA GTT TCA GGG GAC AG-3' & 5'-TTG CAA ATC CCC AAG AAA AC-3' & 58 & 298 \\
\hline Gabra4 & Gabra4 & AFO90373 & $5^{\prime}$-TGA TAT ATA TGT CAC CAB CTा TGG.3' & 5.GTT ATG GAG ACA GAT TTC TTT CC.3' & 58 & 850 \\
\hline
\end{tabular}


To facilitate further analysis, we selected genespecific primers for the three $\mathrm{GABA}_{\mathrm{A}}$ genes (Table 1). Whereas nucleotide sequence of full-length cDNAs was available for the mouse Gabra2 and Gabrb1 subunit genes (Table 1; Wang et al. 1992; Kamatchi et al. 1995), we obtained partial sequence for the mouse Gabrg1 gene by screening an olfactory bulb cDNA library with a rat Gabrg1 probe (Table 1). For each gene, 5' and 3' PCR assays were developed and used for BAC contig construction. Among 23 positive BAC clones, 13 BACs were selected for nucleotide sequence analysis of the insert ends (Fig. 1). The nonrepetitive insert end sequences provided 19 new STSs (Table 1). STS mapping using all available markers revealed that we had isolated three independent groups of BACs corresponding to the Gabra2, Gabrb1, and Gabrg1 subunit gene regions with no overlaps between the three groups of clones.
To comply with the mouse genome initiative that has designated the $\mathrm{C} 57 \mathrm{BL} / 6 \mathrm{~J}$ genome as a reference strain for genomic sequencing, further BAC isolation in the $\mathrm{GABA}_{\mathrm{A}}$ cluster on mouse chromosome 5 was performed by screening a C57BL/6J BAC library. To efficiently convert a $129 / \mathrm{Sv}$ clone collection into a C57BL/6J BAC contig, we selected 10 STSs for library screening. Sixteen new C57BL/6J BACs were sized and tested for STS and probe content and precisely positioned to the regions already covered by the $129 / \mathrm{Sv}$ BACs. In addition, STSs corresponding to the BAC ends were used to isolate clones that joined the Gabra2 and Gabrg1 groups of BACs, showing that these two genes map within an interval of $370 \mathrm{~kb}$. Furthermore, BAC clones isolated with the D5Mit305 marker filled the gap between the Gabra2 and Gabrb1 BACs. The D5Mit305 marker was the only simple sequence length

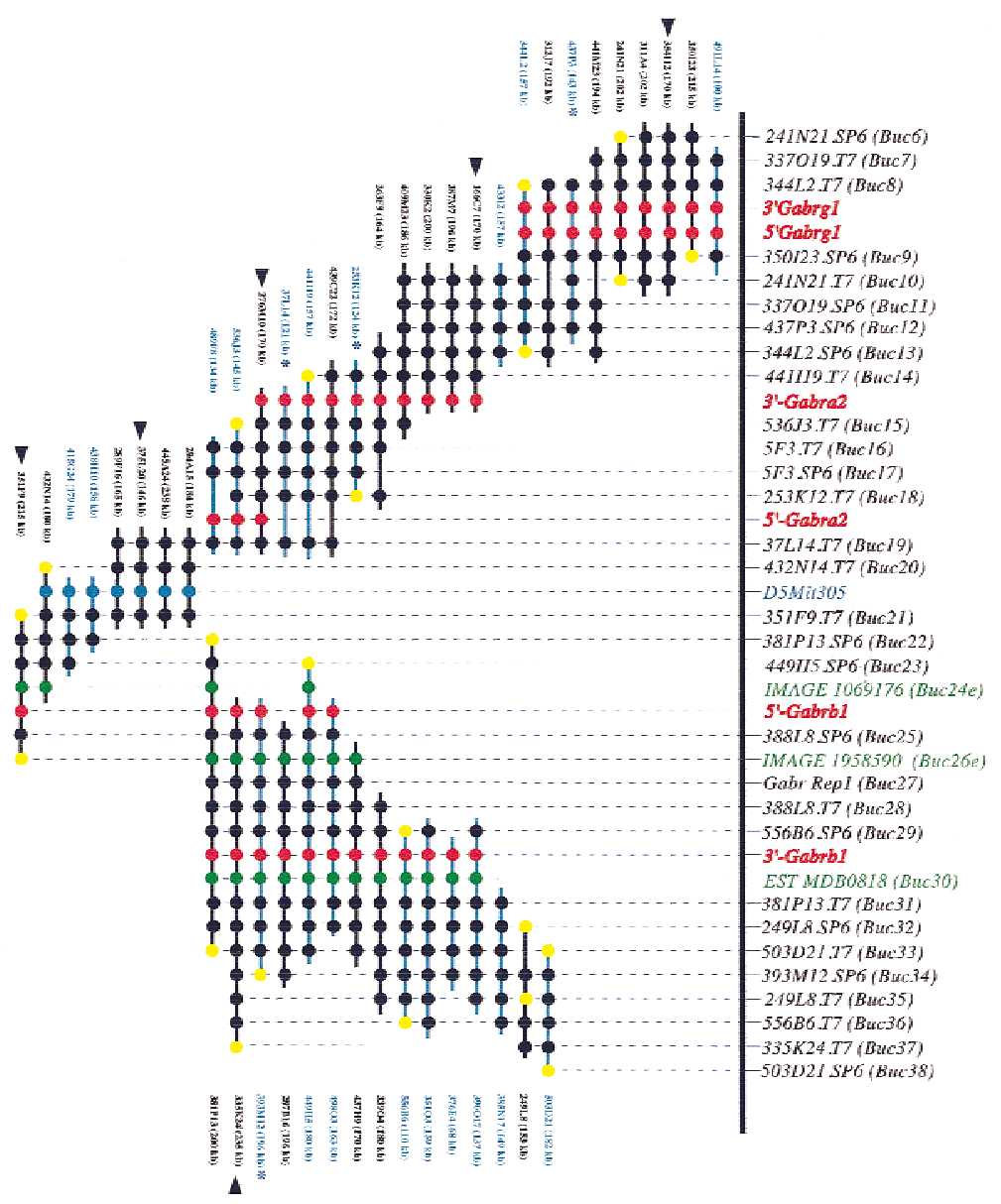

Figure 1 A BAC-based STS/EST-content map of the Gabr gene cluster on mouse chromosome 5 (oriented with centromeric end at left and telomeric end at right). The relative positions of mapped STSs and ESTs are indicated at top, including the corresponding loci names (D5Buc). The isolated BAC clones are shown as horizontal lines with circles along the lines indicating positive STS hits. The STSs were developed from BAC insert ends (black), known genes (red), ESTs (green), and an SSLP marker D5Mit305 (blue). When an STS corresponds to a clone insert end, a yellow circle is present at the end of the clone from which it was derived. BAC clones were isolated from the C57BL/6) library (black lines), from the 129/Sv library (blue lines), or from the Research Genetics CITB library ( ${ }^{*}$ ). The size of each BAC as determined by PFGE analysis is indicated. C57BL/6] BAC clones selected to represent the minimal tiling path are indicated by black arrowheads. The map is displayed with equal spacing between STS/EST markers and the depicted clones together span a distance of $\sim 1300 \mathrm{~kb}$. The orientation of the 5'- and $3^{\prime}$-Gabrg1 markers with respect to surrounding STSs on the contig could not be determined.

\section{Genome Research}


polymorphism (SSLP) marker among 15 markers assigned to the $41 \mathrm{cM}$ interval on the composite genetic map (Kozak and Stephenson 1998) that mapped to the $1.3 \mathrm{Mb}$ region covered by the BAC contig.

The established BAC contig contains 45 BAC clones, covers a physical distance of about $1.3 \mathrm{Mb}$, and provides ordering information for 40 new markers. Among these are 29 STSs designed from BAC-insert ends, 5' - and 3'-specific sequence markers developed from $\mathrm{GABA}_{\mathrm{A}}$ receptor subunit cDNAs, and three new ESTs that were found by sequence homology of BAC ends to mouse EST cDNA clones (Table 1). Overall, this results in an average spacing of 1 marker per $32 \mathrm{~kb}$ within the contig and a five- to sixfold coverage with independent BAC clones. Because of the uneven distribution of STSs within the contig, the number of "hits" per BAC clone varies from 3 to 15. Fourteen C57BL/6Jderived BAC clones were selected for fingerprinting of EcoRI-digested DNA (data not shown). The pattern of EcoRI restriction fragments further confirmed the order of clones established by STS content mapping. This analysis identified six BAC clones that represent a minimal tiling path (Fig. 1). The STS content mapping using $5^{\prime}$ and $3^{\prime}$ gene-specific primer pairs and Southern blot analysis determined the transcriptional orientation of the Gabra2 and Gabrb1 genes with respect to contig ends and thus, with respect to each other. The two genes are transcribed in opposite directions (Fig. $1)$.

Finally, a genomic PCR assay specific for the Gabra4 subunit gene was developed from a partial mouse cDNA sequence (Table 1). Primers were chosen from the portion of the gene encoding the aminoterminal extracellular domain (amino acids 72-166) yielding a 280-bp amplicon in brain cDNA and a genomic PCR product of $1.2 \mathrm{~kb}$. A PCR assay using these primers was performed to test for the presence of the Gabra4 gene on the contig (data not shown). We found no evidence that the Gabra4 gene is located within this $\mathrm{GABA}_{\mathrm{A}}$ cluster. We have not discounted the possibility that Gabra4 could be located close to, but not within, the $1.3-\mathrm{Mb}$ region covered by the contig.

Nucleotide sequence analysis was performed on 40 BAC ends. The overall percentage of repetitive sequence detected using RepeatMasker in these BAC endsequences was $17.5 \%$. Three BAC ends contained sequences with high homology to ESTs (Table 1), but no homology to any known gene in the GenBank database. Expression analysis using RT-PCR confirmed that these are indeed transcribed sequences, expressed in several tissues, such as liver, spleen, testis, kidney, lungs and brain (data not shown).

To integrate the Gabrg1-Gabra2-Gabrb1 BAC contig with the existing map of the mouse chromosome 5, we mapped several STSs and chromosome 5 SSLP markers using the mouse whole-genome RH panel. The commonly used T31 panel consists of 100 hybrid cell lines generated with a 3000-rad dose and has been shown to have a retention frequency of 27.6\% (McCarthy et al. 1997). In contrast to genetic mapping, which requires markers with SSLP polymorphism between inbred strains used to generate the cross, PCR-based RH mapping requires markers that are present in mouse and absent in hamster DNA, or alternatively, that the amplicons detected in these DNAs are of different size. This makes RH mapping useful as an aid to anchor clone contigs on the chromosome relative to markers previously mapped or ordered along the chromosome. It also enables quick verification of chromosomal position of BAC clones containing members of large gene families.

To determine the orientation of our BAC contig, we mapped the following STSs: 253K12.T7(D5Buc18), 473P3.SP6(D5Buc12), and an EST developed from the 3'-UTR of the Gabrb1 gene in the T31 RH panel. We also included the SSLP marker D5Mit305 placed on the contig between Gabra2 and Gabrb1 (Fig. 1). PCR analysis of each marker was performed twice and consensus vector scores (Fig. 2) were entered in a data file containing scores for $>50$ loci along mouse chromosome 5 (L. Tarantino, C. Otmani, T. Wiltshire, A. Lengeling, and M. Bucan, unpubl.). Pairwise analysis of the data

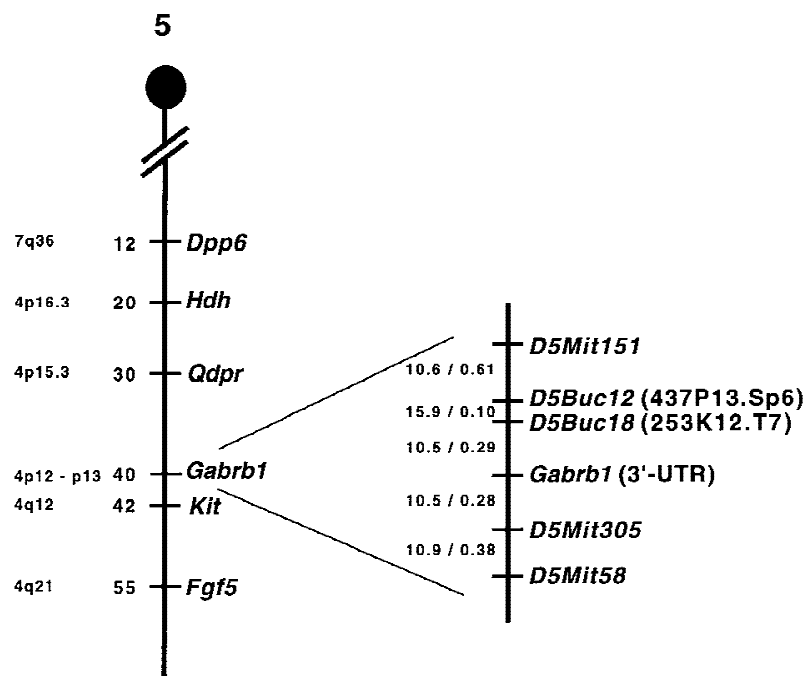

Figure $2 \mathrm{RH}$ map of central mouse chromosome 5. The genetic map of mouse chromosome 5 with some selected loci and their position in $\mathrm{CM}$ (from the centromere) shown for orientation (Kozak and Stephenson 1998). Corresponding regions of homology in the human genome are denoted (http:// www3.ncbi.nlm.nih.gov/Omim/Homology). The RH map of central mouse chromosome 5 from this work is shown in the enlarged area. Indicated are the positions of D5Mit markers and new D5Buc markers isolated from BAC clones with their specified insert end in brackets (Table 1). Pairwise lod scores and distances in centirays are indicated between neighboring loci.The RH mapping data (vector scores) have been deposited at the European Bioinformatics Institute (http://www.ebi.ac.uk/RHdb/ index.html). 
gave a single linkage group for the three $\mathrm{GABA}_{\mathrm{A}}$ receptor loci and several SSLP markers (D5Mit151, D5Mit305, and D5Mit58) localized in the central portion of mouse chromosome 5 (Fig. 2). This analysis confirmed the location of the BAC contig on mouse chromosome 5. Furthermore, using Map Manager QT, we calculated the relative marker order along the chromosome by minimizing the number of occurred breaks and determined the most likely order: cen-D5Mit151D5Buc12 (Gabrg1)-D5Buc18 (Gabra2)-Gabrb1D5Mit58-tel (Fig. 2).

\section{DISCUSSION}

In this report we present a sequence-ready BAC contig spanning the cluster of genes encoding $\mathrm{GABA}_{\mathrm{A}}$ receptor subunits Gabra2, Gabrb1, and Gabrg1 located in the central portion of mouse chromosome 5 . The established contig covers $\sim 1.3 \mathrm{Mb}$, as determined by the sizes of BACs corresponding to a minimal tiling path. The gene order of the three subunit genes on mouse chromosome 5 is the same as in all clusters that are composed of three subunits genes $(\beta-\alpha-\gamma / \epsilon)$ and as observed in the human chromosome 15 cluster, $\alpha$ and $\beta$ subunits are transcribed in opposite directions (Greger et al. 1995). In addition to the genes encoding $\mathrm{GABA}_{\mathrm{A}}$ subunits, this physical map includes three ESTs encoding genes of unknown function, with a widespread tissue expression pattern, and with no corresponding or mapped human ESTs. Although chromosomal localization for several $\mathrm{GABA}_{\mathrm{A}}$ receptor clusters has been determined in the mouse and human genome, a highresolution physical map is only available for the $\mathrm{GABA}_{\mathrm{A}}$ clusters on human chromosomes 15 and 5 (Christian et al. 1998; Kostrzewa et al. 1998). Comparative sequence analysis of coding and noncoding regions of $\mathrm{GABA}_{\mathrm{A}}$ receptor genes, both within a cluster and between different clusters, in the mouse and humans may provide important information concerning the complex regulation of gene expression of members of this large gene family. For example, comprehensive expression analysis indicates overlapping expression of Gabra2, Gabrb1, and Gabrg1 in several regions of the brain, such as the neocortex, hippocampus, basal nuclei, amygdala, and red nucleus of the midbrain (for a summary, see Rabow et al. 1995). Comparative physical mapping and sequencing will shed light on the mechanisms involved in the tandem gene duplication events and transpositions that led to the clustered organization of the $\mathrm{GABA}_{\mathrm{A}}$ receptor genes. Further studies concerning the presence of an additional $\alpha$ subunit $\left(\alpha_{4}\right)$ on human chromosome 4 (McLean et al. 1995), and apparent absence of the mouse ortholog in the immediate vicinity of the $\alpha_{2}$ subunit gene in the corresponding cluster on mouse chromosome 5, may indicate a dynamic evolution of this gene family. Furthermore, the presence or absence of nonrelated genes dispersed among the gene-family members in other clusters will provide useful insight into the timing of rearrangements during the evolution and origin of these genes in different species.

In the mouse, the Gabrg1-Gabra2-Gabrb1 cluster is located proximal to the cluster of classical developmental mutations-dominant spotting $(W)$ and patch $(P h)$, which are caused by mutations or chromosomal rearrangements in the tyrosine kinase receptor genes Kit and Pdgfra (Reith and Bernstein 1991). In the human genome, orthologous genes are located in the centromeric portion of chromosome 4, with the GABRA2, $G A B R B 1$, and GABRG1 loci mapped to the short arm (4p12-p13), and the KIT-PDGFRA cluster on the long arm (4q12-q13) (http://www3.ncbi.nlm.nih.gov/ Omim/Homology/). Sequence analysis of the region between the two clusters in the mouse should aid in determining sequences surrounding the centromere of human chromosome 4 .

The construction of this contig coincides with the launching of an initiative to generate a working draft of the mouse genome sequence by 2003 (Battey et al. 1999). This effort will employ a random strategy for selection of clones that will not involve extensive mapping efforts and construction of sequence-ready BAC contigs prior to sequencing. In the initial phase, however, established contigs such as this, spanning the $\mathrm{GABA}_{\mathrm{A}}$ cluster, will provide a useful template for the generation of long stretches of contiguous genomic sequence in the mouse. A common C57BL/6J BAC library has been designated as the reference library in this sequencing effort (http://bacpac.med.buffalo.edu/ mouse_bac.html). Our data add to the initial evaluation of the high quality of this library, its uniform coverage, and a large average insert size (197 kb). Although the comparative sequence analysis of the $\mathrm{GABA}_{\mathrm{A}}$ clusters will provide important information concerning functional domains in the coding and noncoding regions, BAC clones containing individual $\mathrm{GABA}_{\mathrm{A}}$ subunit genes will provide immediate resources for functional studies.

\section{METHODS}

\section{Isolation and Processing of BAC Clones}

BAC clones were isolated by hybridization of probes to high-density library filters from three different BAC libraries: 129/Sv (Research Genetics, Huntsville, AL), RPCI-22 129/ SvEvTACfBr, and RPCI-23 C57BL/6J BAC libraries (K. Osoegawa, M. Tateno, and P. de Jong, in prep.; for more information, see http://bacpac.med.buffalo.edu/mouse_bac.html). BAC libraries were initially screened with probes from rat Gabra2 cDNA (Khrestchatisky et al. 1991), rat Gabrg1 cDNA (M. Khrestchatisky and A. Tobin, unpubl.), and the mouse Gabrb1 cDNA (Nagle et al. 1995), and subsequent screenings used STSs generated from BAC-end sequences. All radioactive labeling of probes used standard random-primed methods (Feinberg and Vogelstein 1983). 
All BACs isolated were arrayed as colony dot blots in a 96-well format. BACs were grown overnight in $100 \mu$ of Luria broth (LB)/chloramphenicol, spotted onto nylon filters, and then grown for $8 \mathrm{hr}$ on LB agar plates. Filters were processed using alkaline lysis and Proteinase K/Sarkosyl treatment (see http://www.resgen.com/depts/rnd/rapid.html).

BAC DNA was prepared by standard alkaline lysis methods (Sambrook et al. 1989) from $5 \mathrm{ml}$ of overnight culture and resuspended in $40 \mu \mathrm{l}$ of TE buffer. Miniprep DNA (5 $\mu \mathrm{l})$ was digested immediately in a total volume of $20 \mu \mathrm{l}$ with 5 units of NotI enzyme (New England Biolabs, Inc., Beverly, MA) for 2 $\mathrm{hr}$ at $37^{\circ} \mathrm{C}$. Samples were loaded on a $1 \%$ agarose gel in $0.5 \%$ Tris-borate-EDTA (TBE) and subjected to PFGE (Bio-Rad CHEF DR II) for $16 \mathrm{hr}$ at $6 \mathrm{~V} / \mathrm{cm}, 15^{\circ} \mathrm{C}$ with a switching interval from $5 \mathrm{sec}$ to $15 \mathrm{sec}$. BAC insert sizes were assigned from ethidium bromide-stained gels using AlphEase software and an AlphaImager 2000 gel-documentation system (Alpha Innotech, San Leandro, CA). EcoRI digests of freshly prepared miniprep DNA were also used to fingerprint clones according to the methods of Marra et al. (1997). Clone overlap analysis was carried out manually.

\section{Sequencing of BAC-Insert Ends}

BAC DNA for sequencing was prepared from $200 \mathrm{ml}$ of overnight culture according to the modified protocol for BACs using P100 midi-prep columns (Qiagen, Inc., Valencia, CA). Automated dideoxy-terminator cycle sequencing was carried out with SP6 and T7 primers on BAC DNA $(2 \mu \mathrm{g}$ of DNA in a 20- $\mu$ l reaction) using ABI Big Dye Terminator sequencing chemistry with Taq FS polymerase from Applied BioSystems (Foster City, CA). Reaction products were purified by G50 spin columns and analyzed on ABI 377 automated sequencers (DNA Sequencing Facility, Department of Genetics, University of Pennsylvania, Philadelphia).

\section{Development of New STSs and Marker Content Mapping}

BAC end sequence was assessed for development of new STS markers. To determine rodent specific and low complexity repeats, nucleotide sequences were analyzed using RepeatMasker (http://ftp.genome.washington.edu/ cgi-bin/RepeatMasker). Primer 3.0 software (http://wwwgenome.wi.mit.edu/cgi-bin/primer/primer3.cgi) was used for selection of PCR primers. STS content mapping of BACs was determined by hybridization of specific probes to colony dot blots. PCR was performed with diluted mini-prep BAC DNA in $15-\mu$ reactions consisting of $1 \times$ buffer $(20 \mathrm{~mm}$ Tris- $\mathrm{HCl}$ at $\mathrm{pH}$ 8.3, $50 \mathrm{~mm} \mathrm{KCl}$, and $2.5 \mathrm{~mm} \mathrm{MgCl}_{2}$ ), $0.2 \mathrm{~mm}$ each dNTP, $1 \mu \mathrm{M}$ each STS primer, and 0.5 unit of Taq polymerase (Roche, Indianapolis, IN) under the following conditions: $94^{\circ} \mathrm{C}$ for 30 sec, annealing for $30 \mathrm{sec}$ (temperatures listed in Table 1), $72^{\circ} \mathrm{C}$ for $30 \mathrm{sec}$, for 35 cycles.

\section{Screening of cDNA Libraries}

The rat Gabrg1 cDNA probe (1200-bp EcoRV fragment) was used to screen an arrayed mouse olfactory bulb cDNA library (Resource Center/Primary Database of the German Human Genome Project, Max Planck Institute for Molecular Genetics, Berlin-Charlottenburg, Germany). Clone UCDMp608P0343Q2 was isolated, sequenced, and used to design 5 '- and 3' -specific PCR assays for the mouse Gabrg1 gene.

\section{RH Mapping}

T31 RH panel DNAs (Research Genetics, Huntsville, AL) were diluted to $3 \mathrm{ng} / \mu \mathrm{l}$ and $3 \mu \mathrm{l}$ of each cell hybrid clone DNA was used in PCRs. PCR reagents and conditions were previously described. Primers were initially tested on mouse and hamster DNA controls, prior to the analysis of 100-cell hybrid lines. PCR amplicons were run on $2 \%$ agarose gels and the presence or absence of PCR fragments were scored. For each marker the T31 RH panel was typed twice. Data analysis was performed with Map Manager QTb 27 ppc. Distances between neighboring loci (in centirays) were calculated with the RH2PT function of the RH Map program (Lunetta et al. 1996). The RH mapping data (vector scores) have been deposited at the European Bioinformatics Institute (http://www.ebi.ac.uk/RHdb/ index.html).

\section{ACKNOWLEDGMENTS}

We thank Michel Khrestchatisky and Allan Tobin for the rat Gabrga2 and Gabrg1 cDNA probes, Lisa Tarantino and Ali Alavizadeh for help with the RH mapping analysis, Ariel Soiffer for the technical assistance in the initial phase of this project, Nadja Pohl for assistance with the cDNA screen, Lisa Stubbs and Mark LaLande for discussions on gene order in $\mathrm{GABA}_{\mathrm{A}}$ clusters, and Tom Ferraro and Lisa Tarantino for comments on the manuscript. These studies were supported by grants from the National Institutes of Health (HD 28410 and $\mathrm{MH}$ 57855).

The publication costs of this article were defrayed in part by payment of page charges. This article must therefore be hereby marked "advertisement" in accordance with 18 USC section 1734 solely to indicate this fact.

\section{REFERENCES}

Battey, J., E. Jordan, D. Cox, and W. Dove. 1999. An action plan for mouse genomics. Nat. Genet. 21: 73-75.

Bormann, J., O. P. Hamill, and B. Sakmann. 1987. Mechanism of anion permeation through channels gated by glycine and gamma-aminobutyric acid in mouse cultured spinal neurones. $J$. Physiol. 385: 243-286.

Boyd, Y., H.J. Blair, P. Cunliffe, P. Denny, E. Gormally, and G.E. Herman. 1998. Encyclopedia of the mouse genome VII. Mouse chromosome X. Mamm. Genome 8: 361-377.

Brooks-Kayal, A.R., M.D. Shumate, H. Jin, T.Y. Rikhter, and D.A. Coulter. 1998. Selective changes in single cell GABA $\mathrm{A}_{\mathrm{A}}$ receptor subunit expression and function in temporal lobe epilepsy. Nat. Med. 4: 1166-1172.

Buckle, V.J., N. Fujita, A.S. Ryder-Cook, J.M. Derry, P.J. Barnard, R.V. Lebo, P.R. Schofield, P.H. Seeburg, A.N. Bateson, and M.G. Darlison. 1989. Chromosomal localization of $\mathrm{GABA}_{\mathrm{A}}$ receptor subunit genes: Relationship to human genetic disease. Neuron 3: $647-654$.

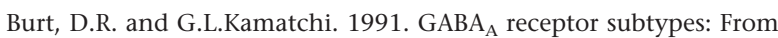
pharmacology to molecular biology. FASEB J. 5: 2916-2923.

Christian, S.L., N.K. Bhatt, S.A. Martin, J.S. Sutcliffe, T. Kubota, B. Huang, A. Mutirangura, A.C. Chinault, A.L. Beaudet, and D.H. Ledbetter. 1998. Integrated YAC contig map of the Prader-Willi/Angelman region on chromosome 15q11-q13 with average STS spacing of $35 \mathrm{~kb}$. Genome Res. 8: 146-157.

Culiat, C.T., L.J. Stubbs, C.S. Montgomery, L.B. Russell, and E.M. Rinchik. 1994. Phenotypic consequences of deletion of the $\gamma 3$, $\alpha 5$, or $\beta 3$ subunit of the type A gamma-aminobutyric acid receptor in mice. Proc. Natl. Acad. Sci. 91: 2815-2818.

Cutting, G.R., S. Curristin, H. Zoghbi, B. O'Hara, M.F. Seldin, and G.R. Uhl. 1992. Identification of a putative gamma-aminobutyric acid (GABA) receptor subunit rho2 cDNA and colocalization of the genes encoding rho2 (GABRR2) and rho1 (GABRR1) to 
human chromosome 6q14-q21 and mouse chromosome 4. Genomics 12: 801-806.

Danciger, M., D.B. Farber, and C.A. Kozak. 1993. Genetic mapping of three $\mathrm{GABA}_{\mathrm{A}}$ receptor-subunit genes in the mouse. Genomics 16: $361-365$.

Feinberg, A.P. and B. Vogelstein. 1983. A technique for radiolabeling DNA restriction endonuclease fragments to high specific activity. Anal. Biochem. 132: 6-13.

Garrett, K.M., D. Haque, D. Berry, I. Niekrasz, J. Gan, A. Rotter, and T.W. Seale. 1997. The $\mathrm{GABA}_{\mathrm{A}}$ receptor $\alpha 6$ subunit gene (Gabra6) is tightly linked to the $\alpha 1-\gamma 2$ subunit cluster on mouse chromosome 11. Mol. Brain Res. 45: 133-137.

Glatt, K., H. Glatt, and M. Lalande. 1997. Structure and organization of GABRB3 and GABRA5. Genomics 41: 63-69.

Greger, V., J.H. Knoll, E. Woolf, K. Glatt, R.F. Tyndale, T.M. DeLorey, R.W. Olsen, A.J. Tobin, J.M. Sikela, and Y. Nakatsu. 1995. The gamma-aminobutyric acid receptor $\gamma_{3}$ subunit gene (GABRG3) is tightly linked to the $\alpha_{5}$ subunit gene (GABRA5) on human chromosome 15q11-q13 and is transcribed in the same orientation. Genomics 26: 258-264.

Kamatchi, G.L., P. Kofuji, J.B. Wang, J.C. Fernando, Z. Liu, J.R. Mathura, Jr., and D.R. Burt. 1995. GABA receptor $\beta_{1}, \beta_{2}$, and $\beta_{3}$ subunits: Comparisons in DBA/2J and C57BL/6J mice. Biochim. Biophys. Acta 1261: 134-142.

Kaupmann, K., K. Huggel, J. Heid, P.J. Flor, S. Bischoff, S.J. Mickel, G. McMaster, C. Angst, H. Bittiger, W. Froestl, and B. Bettler. 1997. Expression cloning of $\mathrm{GABA}_{\mathrm{B}}$ receptors uncovers similarity to metabotropic glutamate receptors. Nature 386: 239-246.

Kaupmann, K., B. Malitschek, V. Schuler, J. Heid, W. Froestl, P. Beck, J. Mosbacher, S. Bischoff, A. Kulik, R. Shigemoto, A. Karschin, and B. Bettler. 1998. GABA $\mathrm{B}_{\mathrm{B}}$-receptor subtypes assemble into functional heteromeric complexes. Nature 396: 683-687.

Khestchatisky, M., A.J. MacLennan, N.J. Tillakaratne, M.Y. Chiang, and A.J. Tobin. 1991. Sequence and regional distribution of the mRNA encoding the $\alpha_{2}$ polypeptide of rat gamma-aminobutyric acid A receptors. J. Neurochem. 56: 1717-1722.

Kirkness, E.F., J.W. Kusiak, J.T. Fleming, J. Menninger, J.D. Gocayne, D.C. Ward, and J.C. Venter. 1991. Isolation, characterization, and localization of human genomic DNA encoding the beta 1 subunit of the GABA A receptor (GABRB1). Genomics 10: 985-995.

Kostrzewa, M., B.W. Krings, M.J. Dixon, K. Eppelt, A. Kohler, D.L. Grady, D. Steinberger, N.D. Fairweather, R.K. Moyzis, A.P. Monaco, and U. Muller. 1998. Integrated physical and transcript map of 5q31.3-qter. Eur. J. Hum. Genet. 6: 266-274.

Kozak, C.A. and D.A. Stephenson. 1998. Encyclopedia of the mouse genome VII. Mouse chromosome 5. Mamm. Genome 8: S91-113.

Levin, M.L., A. Chatterjee, A. Pragliola, K.C. Worley, M. Wehnert, O. Zhuchenko, R.F. Smith, C.C. Lee, and G.E. Herman. 1996. A comparative transcription map of the murine bare patches $(\mathrm{Bpa})$ and striated (Str) critical regions and human Xq28. Genome Res. 6: 465-477.

Lunetta, K.L., M. Boehnke, K. Lange, and D.R. Cox. 1996. Selected locus and multiple panel models for radiation hybrid mapping. Am. J. Hum. Genet. 59: 717-725.

Marra, M.A., T.A. Kucaba, N.L. Dietrich, E.D. Green, B. Brownstein,
R.K. Wilson, K.M. McDonald, L.W. Hillier, J.D. McPherson, and R.H. Waterston. 1997. High-throughput fingerprint analysis of large-insert clones. Genome Res. 7: 1072-1084.

McCarthy, L.C., J. Terrett, M.E. Davis, C.J. Knights, A.L. Smith, R. Critcher, K. Schmitt, J. Hudson, N.K. Spurr, and P.N. Goodfellow. 1997. A first-generation whole genome-radiation hybrid map spanning the mouse genome. Genome Res. 7: 1153-1161.

McLean, P.J., D.H. Farb, and S.J. Russek. 1995. Mapping of the $\alpha_{4}$ subunit gene (GABRA4) to human chromosome 4 defines an $\alpha_{2}-\alpha_{4}-\beta_{1}-\gamma_{1}$ gene cluster: Further evidence that modern GABA receptor gene clusters are derived from an ancestral cluster. Genomics 26: 580-586.

Nagle, D.L., C.A. Kozak, H. Mano, V.M. Chapman, and M. Bucan. 1995. Physical mapping of the Tec and Gabrb1 loci reveals that the $W^{\text {sh }}$ mutation on mouse chromosome 5 is associated with an inversion. Hum. Mol. Genet. 4: 2073-2079.

Nakatsu, Y., R.F. Tyndale, T.M. DeLorey, D. Durham-Pierre, J.M. Gardner, H.J. McDanel, Q. Nguyen, J. Wagstaff, M. Lalande, and J.M. Sikela. 1993. A cluster of three $\mathrm{GABA}_{\mathrm{A}}$ receptor subunit genes is deleted in a neurological mutant of the mouse $p$ locus. Nature 364: 448-450.

Rabow, L.E., S.J. Russek, and D.H. Farb. 1995. From ion currents to genomic analysis: Recent advances in $\mathrm{GABA}_{\mathrm{A}}$ receptor research. Synapse 21: 189-274.

Reith, A.D. and A. Bernstein. 1991. Molecular biology of the W and Steel loci. In Genome analysis: Genes and phenotypes (ed. K.E. Davies and S.M. Tilghman), Vol. 3, pp. 105-133. Cold Spring Harbor Laboratory Press, Cold Spring Harbor, NY.

Sambrook, J., E.F. Fritsch, and T. Maniatis. 1989. Molecular cloning: A laboratory manual. Cold Spring Harbor Laboratory Press, Cold Spring Harbor, NY.

Seeburg, P.H., W. Wisden, T.A. Verdoorn, D.B. Pritchett, P. Werner, A. Herb, H. Luddens, R. Sprengel, and B. Sakmann. 1990. The $\mathrm{GABA}_{\mathrm{A}}$ receptor family: Molecular and functional diversity. Cold Spring Harb. Symp. Quant. Biol. 55: 29-40.

Shiah, I.S. and L.N. Yatham. 1998. GABA function in mood disorders: An update and critical review. Life Sci. 63: 1289-1303.

Wang, J.B., P. Kofuji, J.C. Fernando, S.J. Moss, R.L. Huganir, and D.R. Burt. 1992. The $\alpha_{1}, \alpha_{2}$, and $\alpha_{3}$ subunits of $\mathrm{GABA}_{\mathrm{A}}$ receptors: Comparison in seizure-prone and -resistant mice and during development. J. Mol. Neurosci. 3: 177-184.

Wilcox, A.S., J.A. Warrington, K. Gardiner, R. Berger, P. Whiting, M.R. Altherr, J.J. Wasmuth, D. Patterson, and J.M. Sikela. 1992. Human chromosomal localization of genes encoding the $\gamma_{1}$ and $\gamma_{2}$ subunits of the gamma-aminobutyric acid receptor indicates that members of this gene family are often clustered in the genome. Proc. Natl. Acad. Sci. 89: 5857-5861.

Wilke, K., R. Gaul, S.M. Klauck, and A. Poustka. 1997. A gene in human chromosome band Xq28 (GABRE) defines a putative new subunit class of the $\mathrm{GABA}_{\mathrm{A}}$ neurotransmitter receptor. Genomics 45: $1-10$.

Wisden, W. and P.H. Seeburg. 1992. GABA receptor channels: From subunits to functional entities. Curr. Opin. Neurobiol. 2: 263-269.

Received April 26, 1999; accepted in revised form June 10, 1999.

738 Genome Research 


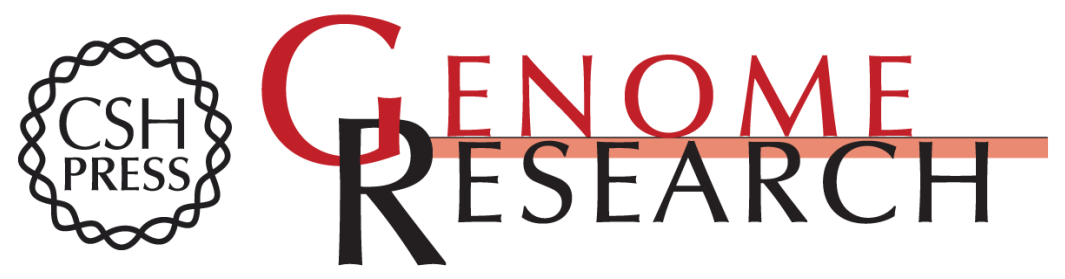

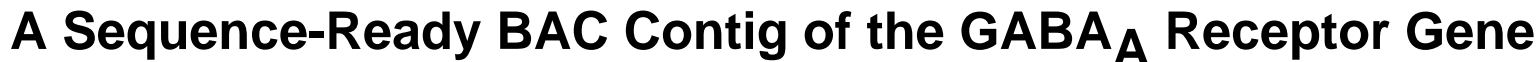 Cluster Gabrg1-Gabra2-Gabrb1 on Mouse Chromosome 5}

Andreas Lengeling, Tim Wiltshire, Chris Otmani, et al.

Genome Res. 1999 9: 732-738

Access the most recent version at doi:10.1101/gr.9.8.732

References This article cites 33 articles, 7 of which can be accessed free at:

http://genome.cshlp.org/content/9/8/732.full.html\#ref-list-1

\section{License}

Email Alerting Receive free email alerts when new articles cite this article - sign up in the box at the Service top right corner of the article or click here.

\section{Affordable, Accurate Sequencing.}

